\title{
Możliwość odwołania członka organu uchwałodawczego jednostki pomocniczej gminy ${ }^{1}$
}

\author{
A possibility to dismiss a member of a legislative body of an auxiliary unit \\ of a commune
}

\begin{abstract}
In the case-law and in the literature on the subject, there is disagreement as to whether it is permissible to regulate in the statute of the auxiliary unit the principles and procedure for dismissal of a member of the resolution body of that auxiliary unit. Such a possibility also does not arise directly from the Act on Communal Self-government, as it does not regulate the issue of dismissal of members of legislative bodies coming from direct elections. If it is assumed that a community council had been given the opportunity to make decisions on specific matters related to the local community, then it is justified in the context of the interests of that community to discipline community councillors, e.g., depending on their attendance at the council sessions.
\end{abstract}

Keywords: commune, auxiliary unit, communal self-government

W orzecznictwie oraz w literaturze przedmiotu brak zgody co do tego, czy dopuszczalne jest uregulowanie w statucie jednostki pomocniczej zasad i trybu odwołania członka organu uchwałodawczego tej jednostki pomocniczej. Możliwość taka nie wynika również wprost z ustawy o samorządzie gminnym, w której nie poruszono problematyki odwoływania członków organów uchwałodawczych pochodzących z bezpośrednich wyborów. Jeżeli przyjąć, że rada osiedla otrzymała możliwość podejmowania decyzji w określonych sprawach dotyczących wspólnoty lokalnej, to zasadna w kontekście interesów tej wspólnoty wydaje się możliwość dyscyplinowania radnych osiedli np. w zależności od ich frekwencji podczas sesji rady.

Słowa kluczowe: gmina, jednostka pomocnicza, samorząd gminny

doktor nauk prawnych, ekspert ds. legislacji Biura Analiz Sejmowych • Kancelaria Sejmu, Biuro Analiz Sejmowych, Wydział Analiz Prawnych, Zespół Prawa Publicznego, WARSZAWA, POLSKA -

beata.binkowska-artowicz@sejm.gov.pl.https://orcid.org/0000-0002-9172-5458

\section{Przedmiot opinii}

Przedmiotem opinii jest odpowiedź na następujące pytanie posła: „Czy w porządku prawnym Rzeczypospolitej Polskiej możliwe jest wygaszenie mandatu członka organu uchwałodawczego jednostki pomocniczej gminy, o której mowa w art. 5 ustawy z dnia 8 marca 1990 r. o samorządzie gminnym (t.j. Dz.U. z 2019 r.

1 Opinia prawna w sprawie możliwości odwołania członka organu uchwałodawczego jednostki pomocniczej gminy sporządzona 30 stycznia 2020 r. na zlecenia posła Klubu Parlamentarnego Prawo i Sprawiedliwość; BAS-WAP-145/20. 
poz. 506 z późn. zm.), powołanego w wyborach przez mieszkańców w wypadku jego długotrwałego nieuczestniczenia w pracach organu?".

Poseł powołał się na treść załącznika do uchwały nr LXIX/1307/06 Rady Miasta Bydgoszczy z dnia 31 maja 2006 r., zawierającego Statut Osiedla - jednostki pomocniczej Miasta Bydgoszczy, oraz wyroki sądów administracyjnych - NSA z dnia 17 kwietnia 2019 r., sygn. akt II OSK 1528/17, i WSA w Kielcach z dnia 17 kwietnia 2019 r., sygn. akt II OSK 1528/17 (wyrok prawomocny).

Opinia została przygotowana na zlecenie posła Klubu Parlamentarnego Prawo i Sprawiedliwość, przyjęte do realizacji przez Biuro Analiz Sejmowych 17 stycznia $2020 \mathrm{r}$.

Opinię przygotowano w oparciu o stan prawny aktualny na dzień jej sporządzenia. W opinii uwzględniono m.in. regulacje ustawy z dnia 8 marca $1990 \mathrm{r}$. o samorządzie gminnym (t.j. Dz.U. 2019, poz. 506, ze zm.; dalej: u.s.g.).

Należy zastrzec, że Biuro Analiz Sejmowych nie jest uprawnione do prezentowania stanowiska w sprawach indywidualnych, które mogą stać się przedmiotem postępowania prowadzonego przed właściwymi organami władzy publicznej. Przygotowywane w Biurze opinie, w tym również przedmiotowa, odnoszą się do zagadnień generalnych i abstrakcyjnych, czyli do hipotetycznych, a nie konkretnych stanów faktycznych.

\section{Uzasadnienie tez opinii}

\section{Obowiązujący stan prawny}

Zgodnie $\mathrm{z}$ art. 5 ust. 1 u.s.g.: „Gmina może tworzyć jednostki pomocnicze: sołectwa oraz dzielnice, osiedla i inne. Jednostką pomocniczą może być również położone na terenie gminy miasto”. Stosownie do art. 35 ust. 1 u.s.g.: „Organizację i zakres działania jednostki pomocniczej określa rada gminy odrębnym statutem, po przeprowadzeniu konsultacji z mieszkańcami”. Zgodnie z ust. 3 powyższego artykułu: „Statut jednostki pomocniczej określa w szczególności: 1) nazwę i obszar jednostki pomocniczej; 2) zasady i tryb wyborów organów jednostki pomocniczej; 3) organizację i zadania organów jednostki pomocniczej; 4) zakres zadań przekazywanych jednostce przez gminę oraz sposób ich realizacji; 5) zakres i formy kontroli oraz nadzoru organów gminy nad działalnością organów jednostki pomocniczej”. Na mocy art. 37 ust. 1 u.s.g.: „Organem uchwałodawczym w dzielnicy (osiedlu) jest rada o liczbie członków ustalonej według art. 17, nie więcej jednak niż 21".

Przed przystąpieniem do analizy dopuszczalności zawarcia w statucie jednostki pomocniczej (np. osiedla) trybu odwołania członków organu uchwałodawczego (np. rady osiedla czy dzielnicy) należy zwrócić uwagę na dwie kwestie. Po pierwsze, katalog zakresu spraw, które mogą zostać uregulowane w statucie jednostki pomocniczej, jest przykładowy, na co wskazuje użycie we wstępie do 
wyliczenia w art. 35 ust. 3 u.s.g. zwrotu „W szczególności”. Po drugie, obecnie obowiązujące przepisy ustawy o samorządzie gminnym nie dotyczą problematyki odwoływania członków organów uchwałodawczych pochodzących z bezpośrednich wyborów ${ }^{2}$.

W odniesieniu do kwestii katalogu przedmiotowego dotyczącego statutu jednostki pomocniczej należy wskazać na treść art. 94 zdanie drugie Konstytucji Rzeczypospolitej Polskiej z dnia 2 kwietnia 1997 r. (Dz.U. nr 78, poz. 483, ze zm.; dalej: Konstytucja RP). Na mocy tego przepisu: „Organy samorządu terytorialnego oraz terenowe organy administracji rządowej, na podstawie i w granicach upoważnień zawartych w ustawie, ustanawiają akty prawa miejscowego obowiązujące na obszarze działania tych organów”. Zgodnie z art. 40 ust. 2 pkt 1 u.s.g.: „Na podstawie niniejszej ustawy organy gminy mogą wydawać akty prawa miejscowego w zakresie wewnętrznego ustroju gminy oraz jednostek pomocniczych".

Statut jednostki pomocniczej jest rodzajem aktu prawa miejscowego, wydanego w formie uchwały rady gminy (art. 41 ust. 1 u.s.g.) i obowiązującego na obszarze danej jednostki pomocniczej. Upoważnienie do uchwalenia statutu znajduje się w cytowanym wyżej art. 35 u.s.g. Normatywna zawartość statutu, jako aktu prawa miejscowego, musi pozostawać w zgodzie z ustawami (art. 94 Konstytucji RP).

Odnosząc się do braku w ustawie o samorządzie gminnym przepisów dotyczących odwoływania członków np. rad osiedla, należy wskazać, że przepisy regulujące tę materię w zakresie radnych gminy znajdują się w ustawie $\mathrm{z}$ dnia 5 stycznia 2011 r. - Kodeks wyborczy (t.j. Dz.U. 2019, poz. 684, ze zm.). I tak na mocy art. $383 \$ 1$ Kodeksu wyborczego: „Wygaśnięcie mandatu radnego następuje w przypadku:

- śmierci;

- utraty prawa wybieralności lub nieposiadania go w dniu wyborów;

- odmowy złożenia ślubowania;

- pisemnego zrzeczenia się mandatu;

- naruszenia ustawowego zakazu łączenia mandatu radnego z wykonywaniem określonych w odrębnych przepisach funkcji lub działalności;

- wyboru na wójta, posła na Sejm, senatora albo posła do Parlamentu Europejskiego;

- niezłożenia w terminach określonych w odrębnych przepisach oświadczenia o swoim stanie majątkowym".

Należy w tym miejscu zauważyć, że wśród przyczyn wygaśnięcia mandatu nie znajduje się absencja na sesjach rady gminy, mimo iż uczestnictwo w obradach należy do obowiązków radnego (art. 24 ust. 1 u.s.g.).

2 P. Lisowski, Problemy z jakościa prawa administracyjnego na przykładzie jednostek pomocniczych gmin [w:] Kryzys prawa administracyjnego?, t. I, Jakość prawa administracyjnego, red. D.R. Kijowski et al., Warszawa 2012, SIP LEX OMEGA. 
Z kolei w art. 97 u.s.g. ustawodawca przewidział mechanizm dyscyplinujący radnych gminy: „W razie nierokującego nadziei na szybką poprawę i przedłużającego się braku skuteczności w wykonywaniu zadań publicznych przez organy gminy, Prezes Rady Ministrów, na wniosek ministra właściwego do spraw administracji publicznej, może zawiesić organy gminy i ustanowić zarząd komisaryczny na okres do dwóch lat, nie dłużej jednak niż do wyboru rady oraz wójta na kolejną kadencję". Przepisu takiego brakuje jednak w odniesieniu do organów jednostki pomocniczej (np. rady osiedla). Brak również przepisów odsyłających, na mocy których można byłoby stosować odpowiednie regulacje ustawy o samorządzie gminnym lub Kodeksu wyborczego do organów jednostki pomocniczej.

\section{Stanowisko orzecznictwa sądowoadministracyjnego oraz poglądy doktryny}

Zarówno w orzecznictwie, jak i w literaturze przedmiotu brakuje zgody co do tego, czy dopuszczalne jest uregulowanie w statucie jednostki pomocniczej zasad odwołania (przesłanek wygaśnięcia mandatu) członka organu ustawodawczego tej jednostki pomocniczej.

W piśmiennictwie wskazuje się: „Choć ustawodawca nie postanowił expressis verbis o uregulowaniu zasad odwoływania członków organów jednostek pomocniczych w statucie gminy, to słusznym wydaje się, by znalazły się one również w tym akcie prawnym"3. Możliwość odwoływania członków organów uchwałodawczych przewidziano także w niektórych statutach jednostek pomocniczych ${ }^{4}$. W wyroku z dnia 17 kwietnia 2019 r., sygn. akt II OSK 1528/17, Naczelny Sąd Administracyjny przyjął następujące stanowisko: „Okoliczność, że ustawodawca sprecyzował tryb wyboru sołtysa (i członków rady sołeckiej) w drodze głosowania tajnego oznacza tylko tyle, że w statucie jednostki pomocniczej nie można odmiennie określić sposób głosowania nad wyborem do ww. organów sołectwa. Nie można zaś domniemywać, [...] że skoro ustawodawca uregulował sposób wyboru sołtysa, to należy uznać, że w identyczny sposób następuje również odwołanie sołtysa. Domniemanie nie jest i nie może być kryterium nadzoru nad działalnością organów samorządu. Zgodnie z art. 171 ust. 1 Konstytucji RP działalność samorządu terytorialnego podlega nadzorowi z punktu

\section{Augustyniak, Jednostki pomocnicze gminy, 2010, SIP LEX OMEGA.}

4 Np. powoływany w treści zlecenia statut Osiedla-Jednostki Pomocniczej Miasta Bydgoszczy, stanowiący załącznik do uchwały nr LXIX/1307/06 Rady Miasta Bydgoszczy z dnia 31 maja 2006 r., a także statut Osiedla Miejskiego Pogodno, stanowiący załącznik do uchwały Rady Miasta Szczecin nr XXIX/775/17 z dnia 25 kwietnia 2017 r., http://bip.um.szczecin.pl/files/8ABE891AD4BA4D3A95604E3EA54DE9D7/775.pdf [dostęp 29 stycznia 2020 r.], oraz statut Rady Osiedla „Bagienna” w Biłgoraju, stanowiący załącznik nr 9 do uchwały Rady Miasta Biłgoraj nr XXIII/189/08 z dnia 29 lutego 2008 r., https://umbilgoraj.bip.lubelskie.pl/dokp/3129.pdf [dostęp 29 stycznia 2020 r.]. 
widzenia legalności, a legalność ta powinna być interpretowana jako zgodność z prawem (art. 85 u.s.g.). [...]”. Zdaniem NSA nie można uznać, „że skoro dany przepis (art. 36 ust. 2 u.s.g.) reguluje tylko tryb wyboru sołtysa, to tak samo zostało ustawowo uregulowane jego odwoływanie. Gdyby ustawodawca zamierzał objąć ustawową regulacją także odwołanie sołtysa, to uczyniłby to w ustawie. Nie można uznać, że brak w tym zakresie regulacji stanowi wadę ustawy lub jest zaniechaniem prawodawczym. Ustawodawca kierując się zasadą samodzielności pozostawił kwestie regulacji odwoływania (a nawet samej możliwości odwoływania) sołtysa zapisom statutów jednostek pomocniczych. [...] Nietrafna jest argumentacja, jakoby wprowadzenie do statutów jednostek pomocniczych przepisu określającego odwołanie sołtysa w drodze głosowania jawnego stanowiło naruszenie wykładni funkcjonalnej art. 36 ust. 2 u.s.g.”.

Odmienny pogląd co do trybu odwołania organów jednostek pomocniczych gminy wyraził wojewoda podkarpacki w rozstrzygnięciu nadzorczym $\mathrm{z}$ dnia 18 listopada 2019 r., nr P-II.4131.2.409.2019 (Legalis nr 2252814): „Odwołanie sołtysa i rady sołeckiej winno odbywać się w takim samym trybie jak ich powołanie, czyli powinno nastąpić w głosowaniu tajnym, bezpośrednim, przez stałych mieszkańców sołectwa uprawnionych do głosowania”. Analogicznie stwierdzono w literaturze przedmiotu: „[... zgodnie z niepisaną - ale uznawaną w prawie ustrojowym - zasadą odwołać może ten podmiot, który wybrał (powołał), zatem np. w przypadku sołectwa kompetencja do odwołania sołtysa i rady sołeckiej należy do stałych mieszkańców sołectwa. Ponieważ tworzą oni równocześnie organ uchwałodawczy sołectwa - zebranie wiejskie, wniosek o odwołanie sołtysa może być przegłosowany na zebraniu wiejskim, bez przeprowadzania specjalnej procedury"5.

Jednakże w orzecznictwie sądowoadministracyjnym są wyrażane również wątpliwości co do tego, czy dopuszczalne jest odwoływanie członków tych organów na podstawie statutu jednostki pomocniczej. W prawomocnym wyroku z dnia 9 grudnia 2014 r., sygn. akt III SA/Kr 1186/14, Wojewódzki Sąd Administracyjny w Krakowie na tle art. 40 ust. 2 pkt 1 u.s.g. orzekł: „Zawarte w tym przepisie upoważnienie rady gminy do określania «wewnętrznego ustroju gminy oraz jednostek pomocniczych» nie zawiera upoważnienia do wprowadzania w statutach sołectw przesłanki wykluczającej możliwość sprawowania funkcji sołtysa lub członka rady sołeckiej, jaką jest prawomocny wyrok sądu, orzeczony za przestępstwo popełnio-

5 P. Chmielnicki [w:] Komentarz do ustawy o samorządzie gminnym, red. P. Chmielnicki, Warszawa 2004, cyt. za: M. Augustyniak, op. cit. Monika Augustyniak w powyższej monografii powołuje się również na innych przedstawicieli doktryny: „Według A. Agopszowicza zasady i tryb wyboru i odwoływania sołtysa i rady sołeckiej powinny być wzorowane na zasadach wyboru zarządu gmin (określonych na podstawie poprzedniego stanu prawnego przewidującego zarząd gminy jako organ wykonawczy) z pewnymi oczywiście modyfikacjami. Zob. A. Agopszowicz, Ustawa o gminnym samorzadzie terytorialnym. Komentarz, Warszawa 1999, s. 252”. 
ne z winy umyślnej. Taka indywidualna kwalifikacja po stronie osoby piastującej funkcję sołtysa lub członka rady sołeckiej nie stanowi takiej regulacji w zakresie «wewnętrznego ustroju gminy oraz jednostek pomocniczych», która nie wymagałaby szczegółowego upoważnienia, gdyż dotyka kwestii publicznych praw podmiotowych o charakterze politycznym do uczestnictwa we władczej działalności państwa, a zatem przede wszystkim kwestii materialnoprawnych a dopiero w ich następstwie kwestii ustrojowych". W kontekście art. 35 ust. 1 i ust. 3 u.s.g. Wojewódzki Sąd Administracyjny w Krakowie w cytowanym wyżej wyroku uznał: „Zakres upoważnienia obejmujący określanie «organizacji i zakresu działania» jednostki pomocniczej również nie daje podstaw do regulowania w drodze statutu sołectwa publicznych praw podmiotowych jednostek do uczestnictwa we władczej działalności państwa”. Sąd ten wyjaśnił: „Zaskarżone przepisy przedmiotowej uchwały dotyczą biernego prawa wyborczego i wprowadzają dodatkowe, nie przewidziane Konstytucją ani ustawami, ograniczenia tego prawa”.

Podobnie zauważył Naczelny Sąd Administracyjny w wyroku z dnia 6 września 2013 r., II OSK 763/13, stwierdzając, że „regulacja ustroju sołectwa nie daje podstaw do ingerencji w obywatelskie prawo wyborcze przez jego ograniczenie. Regulacja w statucie zasad i trybu wyborów organów jednostek pomocniczych (art. 35 ust. 3 pkt 2) oraz regulacja w statucie zakresu i form kontroli oraz nadzoru organów gminy nad działalnością organów jednostek pomocniczych (art. 35 ust. 3 pkt 5) nie obejmuje materii prawa wyborczego w zakresie ograniczenia biernego prawa wyborczego".

Również Wojewódzki Sąd Administracyjny w Łodzi w prawomocnym wyroku z dnia 8 listopada 2016 r., sygn. akt III SA/Łd 638/16, orzekł: „Paragraf [...] statutów przewiduje możliwość odwołania przez radę gminy sołtysa, który nie wywiązuje się ze swoich obowiązków lub dopuścił się czynu dyskwalifikującego go w opinii środowiska, lub jeżeli dopuścił się przestępstw. Tymczasem wynikająca $\mathrm{z}$ art. 35 ust. 3 pkt 2 u.s.g. kompetencja rady gminy do określenia w statucie zasad i trybu wyborów organów jednostki pomocniczej nie obejmuje uprawnienia do odwoływania organów sołectwa. Rada gminy posiada uprawnienie do uregulowania w statucie kwestii technicznych związanych z zasadami i trybem wyborów organów jednostki pomocniczej m.in. sposobu i formy zgłaszania kandydatów czy sposobu głosowania. $\mathrm{W}$ powołanym przepisie art. 35 ust. 3 pkt 2 u.s.g. nie mieści się kompetencja do uregulowania kwestii związanych z czynnym i biernym prawem wyborczym".

Analogicznej oceny Wojewódzki Sąd Administracyjny w Łodzi dokonał w prawomocnym wyroku z dnia 26 marca 2019 r., sygn. akt III SA/Ld 28/19. Zakwalifikował w nim jako nieuprawnione przekroczenie kompetencji ustawowych zawarty w statucie „zapis, zgodnie z którym jedną z przesłanek wygaśnięcia mandatu sołtysa i członka rady sołeckiej jest utrata prawa wybieralności. Wbrew stanowisku pełnomocnika rady miejskiej uprawnienia wprowadzenia powyższego zapisu nie można wywieść z żadnego przepisu u.s.g., w tym z powołanego 
art. 35 ust. 3 pkt 2 u.s.g., jak również z analogicznego zastosowania przepisów ustawy z 5 stycznia 2011 r. - Kodeks wyborczy (tekst jedn. Dz.U. 2018 r., poz. 754 ze zm.). Powyższa ustawa w art. $492 \$ 1$ pkt 4 w zw. z art. $11 \$ 2$ pkt 1 wprowadza instytucję stwierdzenia wygaśnięcia mandatu wójta w przypadku utraty prawa wybieralności lub braku takiego prawa w dniu wyborów. Instytucja ta [...] nie ma zastosowania do sołtysa, czy też członka rady sołeckiej. Wskazać należy, że przyznane organom władzy publicznej kompetencje prawotwórcze muszą być realizowane w sposób ścisły, wykluczający jakąkolwiek ich interpretację, czy to rozszerzającą, czy też zawężającą. Tym samym zawarta w [...] [Statucie] przesłanka wygaśnięcia mandatu sołtysa i członka rady sołeckiej, z uwagi na utratę prawa wybieralności, nie znajduje oparcia w obowiązujących przepisach i w sposób istotny narusza art. 35 ust. 3 pkt 2, art. 36 ust. 2 oraz art. 2 i art. 7 Konstytucji RP”. Również w rozstrzygnięciu nadzorczym Wojewody Warmińsko-Mazurskiego z dnia 5 maja 2011 r., nr PN.4131.159.2011 (legalis nr 367115), stwierdzono: „Rada gminy nie może zawrzeć w statucie sołectwa zapisu, że wygaśnięcie mandatu sołtysa lub członka rady sołeckiej następuje wskutek «prawomocnego skazującego wyroku sądu, orzeczonego za przestępstwo umyślne»”.

Podobnie część przedstawicieli doktryny uznaje za kontrowersyjne ustanawianie w statutach podstaw do odwoływania organów jednostek pomocniczych gminy pochodzących z bezpośrednich wyborów (sołtys, rada osiedla). Wskazuje się bowiem: „W istocie sprowadzałoby się to przecież do ustanowienia instytucji referendum odwoławczego (lub o cechach takiego referendum). Tymczasem na poziomie gminy tego rodzaju kwestie zaliczono do materii ustawowej, co zastrzegł już ustrojodawca (art. 170 Konstytucji $\mathrm{RP}^{6}$ ). Oczywiście, tego rodzaju ograniczeń wprost nie sformułowano w stosunku do takiego głosowania mieszkańców jednostki pomocniczej gminy. Mimo to, nie wydaje się właściwym, by tego rodzaju instytucję można było wprowadzać do ustroju jednostki pomocniczej gminy w drodze samorządowego aktu prawa miejscowego. [...] o ile ustawodawca daje pretekst do statutowej regulacji wyboru organów jednostek pomocniczych, pozostawiając przy tym przestrzeń (przy radach osiedli/dzielnic) dla nawiązywania do mechanizmów właściwych dla wyborów komunalnych do rady gminy, to w tym przepisie (tj. art. 35 ust. 3 pkt 2 u.s.g.) już nie wskazuje na «zasady i tryb ich odwoływania». Uregulowania o takim przeznaczeniu łatwiej zaś wyinterpretować z treści wspominanego już art. 35 ust. 3 pkt 5 u.s.g. [...] Ten przepis bezspornie zaś ogranicza dostępność kompetencji nadzorczych o takim przeznaczeniu do organów gminy” ${ }^{7}$. „Nie należy przy tym akceptować sta-

6 „Członkowie wspólnoty samorządowej mogą decydować, w drodze referendum, o sprawach dotyczących tej wspólnoty, w tym o odwołaniu pochodzącego z wyborów bezpośrednich organu samorządu terytorialnego. Zasady i tryb przeprowadzania referendum lokalnego określa ustawa".

7 P. Lisowski, op. cit. 
nowiska opowiadającego się tak za dopuszczeniem wprowadzania tego rodzaju unormowań (w ww. zakresie) w statutowych aktach prawa miejscowego, jak i za możliwością odwoływania przez legitymujących się czynnym prawem wyborczym mieszkańców jednostki pomocniczej, nawet w sytuacji braku stosownych regulacji w odpowiednim statucie. [...] Subgminny status jednostki pomocniczej gminy implikuje przecież konieczność traktowania także i w tym zakresie kluczowych zagadnień strukturalno-organizacyjnych jako wymagających pierwotnego (chociaż niekoniecznie wyczerpującego) unormowania na poziomie ustawy, a przynajmniej - sformułowania wyraźnego umocowania prawodawczego w tym zakresie. Reasumując, wobec wskazanych uwarunkowań trudno aktualnie uznać statut jednostki pomocniczej gminy za odpowiednie miejsce dla pierwotnego rozstrzygania kwestii dopuszczalności odwoływania organów jednostek pomocniczych wybieranych w warunkach demokracji bezpośredniej"s.

W literaturze podnosi się ponadto następującą kwestię: „Niedopuszczalne jest [...] rozszerzanie kompetencji rady gminy o uprawnienia do odwoływania organów sołectwa, np. sołtysa, który nie wywiązuje się ze swoich obowiązków lub dopuścił się czynu dyskwalifikującego go w opinii środowiska. [...] rada gminy, aby się nie narazić na zarzut przekroczenia upoważnienia ustawowego, powinna w statucie jednostki pomocniczej skupić się wyłącznie na kwestiach technicznych związanych z zasadami i trybem wyboru organów, takich jak np. forma zgłaszania kandydatów, powołanie mężów zaufania czy ustalenie okręgów wyborczych"9.

Reasumując: w świetle zarówno obowiązujących przepisów, jak i braku jednolitości orzecznictwa oraz poglądów doktryny prawa administracyjnego nie sposób dokonać ustalenia, czy dopuszczalne jest wprowadzenie w statucie jednostki pomocniczej gminy regulacji umożliwiającej wygaszenie mandatu członka organu uchwałodawczego tej jednostki. Na ułomność obecnej regulacji prawnej zwraca się uwagę także w piśmiennictwie ${ }^{10}$.

Problem braku wyrażonej expressis verbis możliwości odwoływania członków organów uchwałodawczych jednostek pomocniczych (lub wykluczenia takiej możliwości) wymaga uwagi, zwłaszcza że w piśmiennictwie występuje koncepcja, w której świetle „organ uchwałodawczy jednostki pomocniczej otrzymuje kompetencje rady gminy, niezastrzeżone do jej wyłącznej właściwości” ${ }^{11}$. Jeżeli zatem

8 Ibidem.

9 K. Rokicka-Murszewska, komentarz do art. 35 u.s.g. [w:] Ustawy samorzadowe. Komentarz, red. S. Gajewski, A. Jakubowski, 2018, Legalis.

10 M. Augustyniak, op. cit.; P. Lisowski, op. cit.

11 Tak W. Kisiel, Jednostronne przekazanie kompetencji jednostce działającej we własnym imieniu [w:] Prawo samorządu terytorialnego w Polsce, red. W. Kisiel, Warszawa 2006, s. 72; A. Agopszowicz, Z. Gilowska, M. Taniewska-Peszko, Prawo samorządu terytorialnego $w$ zarysie, Katowice 1999, s. 78, cyt. za: A. Bohdan, Normatywne podstawy funkcjonowania jednostek pomocniczych gminy - prawo dobre czy złe? [w:] Kryzys pra- 
przyjąć, że rada osiedla otrzymała możliwość podejmowania decyzji w określonych sprawach dotyczących wspólnoty lokalnej, to zasadna w kontekście interesów tej wspólnoty wydaje się również możliwość dyscyplinowania radnych osiedli np. w zakresie ich frekwencji podczas sesji rady.

\section{Bibliografia}

Augustyniak M., Jednostki pomocnicze gminy, 2010, SIP LEX OMEGA.

Bohdan A., Normatywne podstawy funkcjonowania jednostek pomocniczych gminy - prawo dobre czy złe? [w:] Kryzys prawa administracyjnego?, t. I, Jakość prawa administracyjnego, red. D.R. Kijowski et al., Warszawa 2012, SIP LEX OMEGA.

Kisiel W., Jednostronne przekazanie kompetencji jednostce działajacej we własnym imieniu [w:] Prawo samorzadu terytorialnego w Polsce, red. W. Kisiel, Warszawa 2006.

Lisowski P., Problemy z jakościa prawa administracyjnego na przykładzie jednostek pomocniczych gmin [w:] Kryzys prawa administracyjnego?, t. I, Jakość prawa administracyjnego, red. D.R. Kijowski et al., SIP LEX OMEGA, Warszawa 2012.

Rokicka-Murszewska K., komentarz do art. 35 u.s.g. [w:] Ustawy samorzadowe. Komentarz, red. S. Gajewski, A. Jakubowski, 2018, Legalis.

wa administracyjnego?, t. I, Jakość prawa administracyjnego, red. D.R. Kijowski et al., Warszawa 2012. 